ISSN: 2162-3104 Print/ ISSN: 2166-3750 Online

Volume 7, Issue 2 (2017), pp. 246-256

(C) Journal of International Students

http://jistudents.org/

\title{
International Student Recruitment: Trends and Challenges
}

\author{
Santa Falcone \\ University of New Mexico, USA
}

\begin{abstract}
This paper provides a review of current trends in international student recruitment. Focusing specifically on recruitment of Chinese students, important aspects of China's educational system relevant to recruitment are presented. Barriers to Chinese student recruitment are then discussed. Successful, employed, international graduates validate domestic institutional value to prospective foreign students and their parents. In that regard, guidance is then offered for domestic universities to use to assist international students to achieve their desired outcomes as an integral part of the institution's international student recruitment strategy.
\end{abstract}

Keywords: Chinese education system, Chinese student recruitment, global student mobility

International student recruitment is one of the primary reasons domestic universities seek partnership with foreign universities (Buck Sutton \& Obst, 2012; Lee, 2014; EAIE, 2014). Pragmatically, the most attractive geographic foreign partners are universities located in nations with large numbers of youth coming to college age (China and India). However, fully successful recruitment for both the domestic university and the international student requires that, once recruited and enrolled at the domestic university, the international student achieve both graduation and post-graduation employment.

Toward that end, this paper provides first a review of current trends in international recruitment. Next, focusing specifically on recruitment of Chinese students, important aspects of China's educational system relevant to recruitment are presented. Then, barriers to Chinese student recruitment 
are discussed. Finally, guidance is offered for domestic universities to use to assist international students to achieve their desired outcomes.

\section{LITERATURE REVIEW}

\section{Current trends in global student mobility}

In 2011, the majority of students traveling outside of their country for higher education (64\%) were hosted by the United States and five other countries (Bhandari \& Blumenthal, 2011). The United States received the largest share (21\%) of these globally mobile students. East Asian nations reported that they seek to increase their share of this education market as this region of the world sends out the greatest number of students. To do so, English language curriculum is being implemented in East Asian universities as well as in universities in other regions of the world.

For many international students, currency fluctuations remain an important factor influencing whether study abroad is financially attractive or prohibitively expensive. In part to mitigate this issue, universities' efforts to export their campuses were noted by these authors, with some universities seeking to establish branch, joint venture, and double degree programs in other countries. However, their attempts have been more numerous than their successes. Crossborder virtual learning was another strategy employed by higher education institutions but it also has not achieved success as a desirable mode of delivery for those seeking overseas education (or, for many, an accessible alternative due to Internet access restrictions in their countries).

India, currently the second largest sending country after China, is projected to become the number one sending country by 2025. Latin American countries count for only $5 \%$ of student mobility and of these, $60 \%$ go to the United States. Effort has begun to try to harmonize the diverse higher education systems in Latin America to enable intra-country mobility for Latin American students. Finally, Bhandari and Blumenthal (2011) noted that regional education hubs were being developed to attract international students. Six hubs were identified and located in: United Arab Emirates, Qatar, Bahrain, Singapore, Hong Kong, and Malaysia.

From the 1940s to 2013, the growth rate in international student enrollment in the United States showed considerable variation (Figure 1). In the decades of the 1950s, 1960s, and 1970s, enrollment grew at an average rate of $6 \%, 11 \%$, and $8 \%$, respectively (IIE, 2014). The highest growth rate to date (21\%) occurred in the 1966-1967 year. The two largest drops in the enrollment growth rate occurred in 1971-1972 (-3.2\%) and in 2003-2004 ($2.4 \%)$. In the 1980 s, it decreased to only $3 \%$ and has remained at that average rate with only minor fluctuations until the 2010s. For the most recent year in the study, 2013-2014, the Institute of International Education (IIE) reported that 886,052 international students enrolled in higher 
education institutions in the United States (IIE, 2014) for an average decade growth rate of $6 \%$. The overwhelming majority of these international students $(274,439)$ studying in the United States were from China. Qi (2015) reported that an estimated 8,000 Chinese students were expelled for either poor grades or cheating from universities in the United States in 2014. To avoid such an undesirable outcome, the selection of those who are the most likely to succeed is very important for both the institutions and the students.

Figure 1: Per cent growth International student enrollment in the United States 1948 - 2014

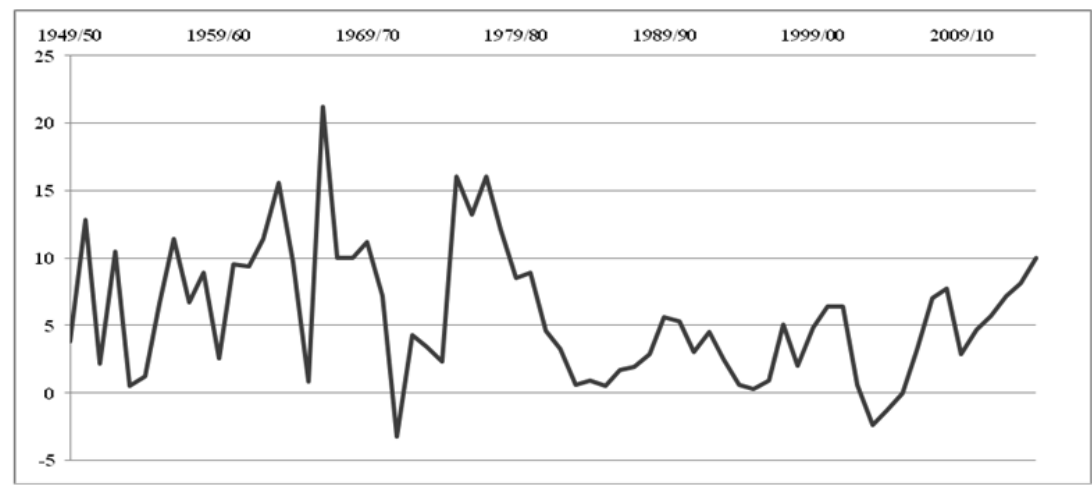

Source: (IIE, 2014)

\section{Regional differences in Chinese student preparedness}

In China, the region of the country the student comes from may impact their college preparedness and likelihood of academic attainment more definitively than their secondary school scores. In the United States, property taxes are collected from all property owners in each locality. That money is aggregated/pooled and then distributed to public schools to fund public education. There are differences in the level of aggregation of the pooling and in the methods of redistribution and there are differences in the amounts collected due to property value differences causing the schools to be more or less resource rich but the general model is the same nationwide and every child residing in every geographic location has the opportunity to be educated from kindergarten to high school without paying additional tuition or extravagant education fees.

In China, "Despite the compulsory education law mandating 9 years of education, children whose families do not pay school fees are not allowed to attend school (Brown and Park, 2002, p. 529).” As a result, childhood education is a decision made by parents based primarily on household financial considerations. Brown and Park (2002) analyzed survey data from 446 rural households and 40 primary and junior secondary 
rural schools in six poor counties in China. Though classes were available from age six, the mean age at which parents began paying for their child to attend school was 7.4 years of age. Of the 472 children in the sample between 5 and 16 years of age, 55 (12\%) had already dropped out of school. Overall, the parental education attainment was low (mean for fathers was 7.3 years, mothers 3.3 years). Parents with more education were more likely to invest in their children's education.

Hannum and Wang (2006), analyzing 2000 census data, affirmed the disparity between rural and urban educational attainment in China. They found that rural areas in western China and Tibet had significantly less educational attainment. For those "who were 20 to 24 years old at census time, being from Tibet was associated with an average of over nine years less education than being from Beijing, the reference category (p. 261).” The disadvantage for western provinces was decreasing (to a level of approximately four years less at the time of the study) but for Tibet the disadvantage was increasing.

Primary school dropout has increased to 54\% at junior high school levels in Northeast China. Chung and Mason (2012) conducted an ethnographic study in a poor, rural area in Yunnan province to probe indepth why students dropped out of primary school in rural areas. Their finding was that there was a mismatch between what villagers and the central government perceive as the purpose, expectations, and value of education. "Parents who have attained a certain level of formal education, with dispositions, manners and values that reflect those of the formal school system [suzhi], are most likely to have their children succeed at school (p. 539)." Villagers with low levels of educational attainment, though they may want their children to succeed at school, are ill-equipped to help their children. Poorly resourced rural schools and teachers and illprepared children all struggle and often fail to achieve the expected success, especially with the new centrally-mandated formats and testing.

Liu (2013) surveyed 960 first year undergraduate college students proportionately drawn from the four different tiers of two Chinese universities located in two different provinces. He affirmed earlier findings that access to the best elite institutions was not likely for students from rural areas. Instead students from urban developed areas with parents who were professionals (technicians, teachers, and doctors) and who attended better secondary schools were much more likely to score high enough on the nationwide college entrance exam (Gaokao) to gain access to the best elite universities.

This rural/urban disparity at the primary and secondary level continues in post-secondary education and post-graduation employment in China (Chan \& Ngok, 2011). In 1996, 100 Chinese universities were selected by the central government for additional funding to increase their quality (the 211 project). In 1998, one third of these selected universities 
received very large concentrated amounts of money to become "world class universities" (the 985 project). Also in 1998, the central government mandated an increase in enrollments in all higher education institutions. These authors compared educational access and outcomes for graduates of 985, 211, non-211, and vocational universities in three provinces: an eastern prosperous, central less prosperous, and a western impoverished. They found that applicants from rural areas were much less likely to be admitted to upper echelon universities. They also found that postgraduation employment and income disparities were significant, depending on the institution granting the degree.

They noted that graduates of upper echelon universities are given household registration in mega cities whereas graduates of other universities are not, excluding the non-elite further from financial benefits and support. The authors further pointed out that accompanying the centrally mandated expansion of university enrollments, tuition at higher education institutions in China increased, making post-secondary education even more inaccessible to the poor. In 2005, the average annual tuition in China was 5,500RMB. In the same time period, urban residents' average annual deposit income was 10,500RMB while rural was only 3,200RMB. Loan programs were introduced by the government but only covered $60 \%$ of those needing assistance. More recently, loan reform decreased access to post-secondary education further by involving parents in repayment of the money borrowed by students. This forced parental repayment of their children's student loans is due, in part, to students not finding jobs after graduation.

\section{Chinese graduates' post-degree employability}

Regarding post degree outcomes, several authors have explored the downturn in employability of Chinese college graduates. Lai, Tian, and Meng (2011) reported that only 74\% of college graduates in 2009 found employment post-graduation in China. Urban graduates were more likely to find satisfactory employment than rural. The authors presented qualitative research that indicated that rural and urban students who live in rural areas do not have the exposure and opportunities available in urban settings and this lack has long-lasting life impacts.

Chan (2012) asserted that household registration and the level of university that applicants graduated from explained the current $70 \%$ employment rate of university graduates. Two alternative explanations (applicants expect too high of wages in the current oversupplied job market or applicants have not obtained a degree that is currently marketable) were of lesser importance, according to this author. Instead, household registration and type of institution were noted to be the first phase of prescreening of job applicants. In this screening, preference was given to those registered in the eastern provinces and graduates of 985 or 211 schools. So, 
others were excluded and never given the chance of the multinational corporate employment they most seek.

Ding, Yang, and Ha (2013) used data from the China Urban Household Survey and the China Health and Nutrition Survey from 1989 to 2009 to identify and explain the trends seen in the rates of return to education in China. They concluded that the central government management of economic market reforms in the late 1980s and early 1990s caused a greatly increased demand for what was, at the time, a stable supply of skilled labor. As a result, wages and the rates of return for education rose. However, when the central government imposed education sector reform in the late 1990s, this caused a great increase in the supply. This increase in supply was accompanied by a reduction in the quality of college graduates. This reduction in quality occurred at a time when the demand for skilled labor continued to be determined by the needs of the construction and manufacturing industries (which grew at much slower rate than the supply of college graduates). Therefore, the rates of return for education began to show a slight decline from 2004-2009.

$\mathrm{Pu}$ (2013) suggested several ways that the decrease in market demand for the oversupply of college graduates might be ameliorated. The first was that the glut in unemployed college graduates will eventually lead parents to decrease their demand for higher education. This author also suggested that encouraging college students to start their own businesses would create jobs that will absorb the excess of graduates. Foreign universities could make their degree programs more attractive to students and their parents in China by developing international entrepreneurship classes specifically designed for business start-ups in other countries.

Because the rate of unemployment for graduates of vocational schools is even greater than that of academic degree colleges, an increase in the quality of vocational education while reducing the price of this type of education was offered as another way to divert the flow of secondary education students away from baccalaureate colleges. Foreign universities could provide highly marketable certificates in cutting edge technologies relevant to their international students' degree concentrations to endeavor to make their international student graduates more marketable both in their home countries as well as in the US.

\section{Common barriers to Chinese student recruitment}

The following study highlights what may be additional barriers that baccalaureate foreign institutions will also face in seeking to increase their Chinese student body. Zhang and Hagedorn (2014) noted that education agents/consultants are paid (by students) to assist international student recruitment by: helping students complete college entrance applications, with the study of languages, counsel on the selection of a college, career guidance, and visa application. In addition, the agents are, at the same time, 
hired by host foreign institutions to recruit for the institutions in the origin country (in this case, China). Though this function is viewed negatively by many US baccalaureate institutions, US community colleges actively work with "placement agencies" worldwide.

The authors conducted Mandarin Chinese interviews about perceptions of US community colleges with one US-specialized, government accredited education agent agency in each of China's eight regions and then transcribed and translated the responses. The agents indicated that US community colleges were a new concept to the Chinese parents and their students. The agents perceived them to be "affordable in cost, a pathway to four-year institutions, and offer programs catering to students' needs (p. 725).”

The agents were aware of the following disadvantages of community colleges. First, the authors noted that the number one reason for consideration of education abroad is the quality of instruction. However, the first drawback of community colleges was noted to be the lower quality of its education. A second drawback was the perception that the majority of US students at community colleges were not motivated or prepared to attend college and would, thereby, have a negative influence on the Chinese student in class with them. In addition, less expensive community colleges usually do not offer the breadth of academic discipline choices available at a research comprehensive four year school. Finally, post-associates degree, the need to complete a second application to transfer to another school to obtain a bachelor degree was seen as a further hindrance to the selection/promotion of community colleges.

Agents identified Chinese parents as their primary clients. Parents perceived community colleges on par with lower level short training schools in China and, thereby, their child's attendance at one would be a loss of face for the family. Agents did not have the same knowledge base about community colleges as they did about four year institutions. Finally, community colleges were not ranked in the most common surveys and community colleges issued a much smaller number of student visas for foreign students. Each of these perceptions by parents and agents can be addressed preemptively by US higher education institutions with informational marketing specifically targeting the concerns of these two groups.

\section{Assist students to achieve their desired outcomes}

The relevance of obtaining more in-depth knowledge about the educational system(s) in each sending country is emphasized in the peerreviewed literature and clearly warranted in regard to the recruitment of Chinese students and students from all other countries worldwide. In addition, Spinks and Wong (2010) emphasized understanding the "psychology and needs" specific to Chinese students. This is important 
because, more recently, with the strengthening of the quality of higher education in Asian countries, Asian parents are questioning the value of sending their children to more distant countries or even outside their own countries at all.

South Korea, Japan, Malaysia, Singapore, and China have seen resulting increases in international student recruitment from Asian countries. These increases, so far, in China (to 250,000), South Korea (to 30,000), and Japan are students studying in language programs. Citing Yang (2007) the authors reported the motivation of Chinese students to travel to receive their education outside of China was due to a combination of some factors specific to China and some to the destination foreign nations. The Chinese factors included the extremely competitive process to obtain the limited number of places in top Chinese universities and the Chinese economic prosperity that has enabled families to be able to afford overseas education. The quality of the education provided and the opportunities for post-graduation employment and migration are factors specific to the foreign nations. Bodycott (2009) found differences between Chinese parents' and Chinese students' top factors impacting their selection of a foreign higher education destination. Bodycott surveyed 250 parents and 100 students and found that post-graduation employment was the most important factor for parents, while the onsite accommodations were cited most frequently by students.

Both emphasized the variety of degree programs, while Chinese parents placed importance on migration opportunities and Chinese students valued the destination universities' facilities, buildings, and grounds. Spinks and Wong (2010) emphasized that universities must assess how they can fulfill parents' and students' needs and desires for education abroad yet not sacrifice their reputations for hoped-for short term gains or be seen as working counter to the sending nation's goals for its traveling students. While, due to academic freedom concerns, "branding" (the creation of a university personality) for universities meets with resistance, these authors suggested that accurately and specifically identifying university strengths has been a successful strategy for Hong Kong University (HKU). In fact, reputation management (branding) was cited by Spinks and Wong (2010) as core to HKU's recruitment success. University reputation in China is based on two factors, admissions standards and university ranking. Admission cutoff scores for each Chinese university are well known. Students and parents need help in understanding scores used by college entrance exams and the university ranking systems in other countries and how they compare to the Chinese system.

Cultural awareness of parental perspectives in the sending country and knowledge about the specific needs of students from the sending country are very important for higher education institutions to develop. Highlighting the importance of successful post-graduation employment can 
orient the institution to develop objectives throughout the student's degree program that will facilitate achievement of this goal. Universities can further enable their own and foreign student success through development of policies and procedures for country-specific: student recruitment, retention, and future alumni relationship.

This could include the development of materials that explain the receiving country's university ranking systems, applicant evaluation procedures, and acceptance rates compared to each sending country's to assist sending countries' parents and students in their selection. Regarding the needs of Chinese students, because of the downtown in employment of university graduates in China, it is important to ensure that Chinese students who are recruited to attend foreign universities are guided to align their interests as much as possible with degrees that will help them to be employable post-graduation. Tracking and communicating post-degree career outcomes of alumni across the university would assist in this regard.

In his study of whether international students do generate the revenue anticipated by universities with their enrollment, Cantwell (2015) found that some but not all US higher education institutions do receive a net financial benefit. The failure of the student to graduate and the possibility that the institution may incur more costs than benefits from international student enrollment are real risks. To avoid them, higher education institutions should conduct continual review and improvement of their international student recruitment, selection and post-enrollment assistance processes to maximize the likelihood of success for both the student and institution.

\section{REFRENCES}

Ash, L. (2016, May 4). Reinventing China's abortion police. BBC News, China. Retrieved from: http://www.bbc.com/news/magazine-36203572

Bhandari, R. \& Blumenthal, P. (eds) (2011). International students and global mobility in higher education: national trends and new directions. New York, NY: Palgrave Macmillian.

Brown, P. \& Park, A. (2002). Education and poverty in rural China. Economics of Education Review, 21, 523-541.

Bodycott, P. (2009). Choosing a higher education study abroad destination. Journal of Research in International Education, 8(3), 349-73.

Buck Sutton, S. \& Obst, D. (2012, January 15). Dynamic time for international partnerships. University World News, Issue 204, Retrieved from: www.universityworldnews.com/article.php?story=2012113202352271

Cantwell, B. (2015). Are international students cash cows? Examining the relationship between new international undergraduate enrollments and institutional revenue at public colleges and universities in the US. Journal of International Students, 5(4), 512-525.

Chan, W., \& Ngok, K. (2011). Accumulating human capital while increasing educational inequality: a study on higher education policy in China. Asia Pacific Journal of Education, 31(3), 293-310.

Chan, W. (2012). Employability does not necessarily lead to competitiveness: An 
employment gap resulting from ascribed factors. Chinese Education and Society, 45(2), 21-37.

Chen, T., \& Jordan, M. (2016, May 1). Why so many Chinese students come to the U.S. WSJ. Retrieved from: http://www.wsj.com/articles/why-so-many-chinesestudents-come-to-the-u-s-1462123552

Chung, C. \& Mason, M. (2012). Why do primary school students drop out in poor, rural China? A portrait sketched in a remote mountain village. International Journal of Educational Development, 32, 537-545.

Ding, X., Yang, S., \& Ha, W. (2013). Trends in the Mincerian rates of return to education in urban China: 1989-2009. Frontiers of Education in China, 8(3), 378-397.

EAIE European Association for International Education. (2014). The EAIE barometer presentation at EAIE annual conference in Prague September 2014, Resource document. Retrieved from: www.eaie.org/blog/barometer-initial-finding

International Business Times. Retrieved from: http://www.ibtimes.com/chinas-steepuniversity-tuition-costs-average-farmer-13-years-income-1101434

Hannum, E. \& Wang, M. (2006). Geography and educational inequality in China. China Economic Review, 17, 253-265.

Hu, C., Wotipka, C. \& Wen, W. (2016). International students in Chinese education: Choices, expectations, and experiences by region of origin. In Bista, K., \& Foster, C. (eds.), Global perspectives and local challenges surrounding international student mobility (pp. 153-178). Hershey, PA: IGI Global.

Hwang, E., Martirosyan, N., \& Moore, G. (2016). A review of literature on adjustment issues of international students: Recommendations for future practices and research. In Bista, K., \& Foster, C. (eds.), Global perspectives and local challenges surrounding international student mobility (pp. 223-242). Hershey, PA: IGI Global.

ICEF (International Consultants for Education and Fairs) Monitor. (2015a, September 2). Four trends that are shaping the future of global student mobility. Retrieved from: http://monitor.icef.com/2015/09/four-trends-that-are-shaping-the-future-of-globalstudent-mobility/

ICEF (International Consultants for Education and Fairs) Monitor. (2015b, November 5). The state of international student mobility in 2015. Retrieved from: http://monitor.icef.com/2015/11/the-state-of-international-student-mobility-in2015/

IIE (Institute of International Education). (2015). "International student enrollment trends, 1948/49-2014/15." Open doors report on international educational exchange. Retrieved from: http://www.iie.org/Research-and-Publications/OpenDoors\#.VyaBBE32bR0

Lai, D., Tian, Y. \& Meng, D. (2011). Differences between the employment of higher education students from the cities and the countryside and the fairness of higher education: from the perspective of employment capability. Chinese Education and Society, 44(1), 3-26

Lee, P. (2014, April 9). Key findings of global study on internationalization. University World News, Issue 315, Retrieved from: www.universityworldnews.com/article.php?story=20140409170137959

Liu, Y. (2013). Meritocracy and the "Gaokao:" A survey study of higher education selection and socio-economic participation in East China. British Journal of Sociology of Education, 34(5-6), 868-8879

Madden Dent, T. \& Laden, R. (2016). Pre-departure cultural preparation for international students: addressing adjustment needs before study abroad. In Bista, K., \& Foster, C. (eds.) Global perspectives and local challenges surrounding international student mobility (pp. 201-222). Hershey, PA: IGI Global.

$\mathrm{Pu}, \mathrm{J}$. (2013). An economic analysis of the external constraints on reform of the higher 
education admissions system in China. Chinese Education and Society, 46 (1), 51 63.

Qi, L. (2015, May 29). U.S. schools expelled 8,000 Chinese students. Wall Street Journal. Retrieved from: http://blogs.wsj.com/chinarealtime/2015/05/29/u-s-schoolsexpelled-8000-chinese-students-for-poor-grades-cheating

Spinks, J., \& Wong, I. (2010). Understanding student recruitment in Mainland China: a case study. International Strategic Information Service Report, 1-29.

Yang, M. (2007). What attracts mainland Chinese students to Australian higher education. Studies in Learning Evaluation, Innovation and Development, 4 (2), 1-12.

Zhang, Y., \& Hagedorn, L. (2014). Chinese education agent views of American community colleges. Community College Journal, 38(8), 721-732.

SANTA FALCONE, PhD, is a professor of public administration. E-mail: falcone@unm.edu 